\title{
Current and future prospects for heat recovery from waste in European district heating systems: A literature and data review
}

Persson, Urban; Münster, Marie

Published in:

Energy

Link to article, DOI:

10.1016/j.energy.2015.12.074

Publication date:

2016

Document Version

Peer reviewed version

Link back to DTU Orbit

Citation (APA):

Persson, U., \& Münster, M. (2016). Current and future prospects for heat recovery from waste in European district heating systems: A literature and data review. Energy, 110, 116-128.

https://doi.org/10.1016/j.energy.2015.12.074

\section{General rights}

Copyright and moral rights for the publications made accessible in the public portal are retained by the authors and/or other copyright owners and it is a condition of accessing publications that users recognise and abide by the legal requirements associated with these rights.

- Users may download and print one copy of any publication from the public portal for the purpose of private study or research.

- You may not further distribute the material or use it for any profit-making activity or commercial gain

- You may freely distribute the URL identifying the publication in the public portal

If you believe that this document breaches copyright please contact us providing details, and we will remove access to the work immediately and investigate your claim 


\section{Current and future prospects for heat recovery from waste in European district heating systems: A literature and data review}

$a^{*}$ Urban Persson

${ }^{b}$ Marie Münster

aSchool of Business, Engineering and Science, Halmstad University, PO Box: 823, S-301 18 Halmstad, Sweden

${ }^{b}$ DTU Management Engineering, Technical University of Denmark, Produktionstorvet, DK - 2800 Lyngby, Denmark

\section{Keywords}

Municipal solid waste, Waste-to-Energy, heat recovery, district heating, European Union

\section{List of abbreviations}

4DH Strategic Research Centre for $4^{\text {th }}$ Generation District Heating Technologies and Systems

CEWEP Confederation of European Waste-to-Energy Plants

EEA European Environment Agency

ETC European Topic Centre

IEA International Energy Agency

IEE Intelligent Energy Europe

ISWA International Solid Waste Association

IVL Swedish Environmental Research Institute

MS (EU) Member State

MSW Municipal Solid Waste

NUTS2 Nomenclature of Territorial Units for Statistics, $2^{\text {nd }}$ level

RDF Refuse Derived Fuels

WTE Waste-to-Energy

1 Abstract

Municipal solid waste has seen increasing annual volumes for many decades in contemporary Europe and constitutes, if not properly managed, an environmental problem due to local pollution and greenhouse gas emissions. From an energy perspective, waste is

\footnotetext{
${ }^{*}$ Corresponding author: Urban Persson, Phone: +4635167405 , urban.persson@hh.se
} 
35 also an alternative fuel for power and heat generation; energy recovery from waste represents

36 an effective measure to reduce landfilling and avoid disposal emissions while simultaneously

37 reducing the equivalent demand for primary energy supply. A key factor for obtaining the full

38 synergetic benefits of this energy recovery is the presence of local heat distribution

39 infrastructures, without which no large-scale recovery and utilisation of excess heat is

40 possible. In this paper, which aims to estimate municipal solid waste volumes available for

41 heat recovery in European district heating systems in 2030, a literature and data review is

42 performed to establish and assess current and future EU waste generation and management.

43 Main conclusions are that more heat can be recovered from current Waste-to-Energy facilities

44 operating at low average heat recovery efficiencies, that efficient incineration capacity is

45 geographically concentrated, and that waste available for heat recovery in 2030 is equally

46 determined by total generation volumes by this year as by future EU deployment levels of

47 district heating. 


\section{Introduction}

Generation of waste is a symbiotic, unfortunate, and potentially detrimental consequence

51 of producing and consuming material goods and services in the world today. Waste,

52 furthermore - if not treated properly - endangers the sanity of local environments, affects

53 the equilibrium of regional and global ecosystems, and may eventually threaten the very

54 foundation for healthy and sustainable life conditions in any community [1-4]. For this reason, waste management represents a critical societal function needed to meet the challenges raised by generated waste flows, be they municipal solid wastes (MSW), industrial wastes, or any other kind of material residues.

In the European Union (EU) context, these circumstances has been apprehended for at least half a century and plausible approaches and solutions to reduce total generation volumes, as well as to arrange proper management measures to treat these, have been conceived and formulated in environmental action programmes [5, 6], in legislation [7-11], and in numerous projects and studies [12-19]. Most urgent, as it represents the least attractive waste management option due to e.g. uncontrolled greenhouse gas emissions, has been efforts to reduce landfilling and land deposits (expressed as early as 1999 in the so called Landfill Directive [20]), an unfortunate practice among EU Member States (MS) still accounting for nearly 40\% of MSW treatment in 2010 [21]. More profoundly, in the recognition of latent interdependencies between waste generation, population growth, and economic activity, the idea of decoupling human well-being from virgin resource use (resource decoupling) have constituted the ground foundation of EU waste policy for the last couple of decades.

If not by landfilling then, according to the principles outlined in most recent EU waste legislation, the Waste Framework Directive [22], waste management should consist of not 
one, but many different treatment options reflecting the characteristics and properties of different waste fractions, and should ideally be initially prevented or minimised. In order of preference, treatment options should moreover be arranged in the following priority order: re-use, recycling, composting, incineration (with and without energy (and heat) recovery), and - when all other options are exhausted - landfilling (deposit). To underline this fundamental strategy for the coming years, a revision of current EU waste legislation has been suggested in 2013 [23] and a proposal for a new coherent waste management policy aligned with the overarching concepts of a circular economy [24, 25] and an energy union [26] is now under discussion [27].

With this clear aim for future European waste management to move "up the waste hierarchy" one immanent, topical, and unneglectable issue concerns the forthcoming fate of energy recovery from waste, or Waste-to-Energy (WTE) [28-30]. It is understood that, in a realised circular economy future, no or little recyclable waste fractions should remain available for this definitive conversion of materials into electricity, heat, flue gas and ashes (at least not non-hazardous fractions), so it is fair to wonder what waste volumes eventually will be left for energy recovery in view of these ambitions?

As will be further investigated and presented in this paper, this question may however not be entirely answered merely by correctly forecasting future European waste generation volumes (which in itself is an arduous and, by nature, speculative undertaking), nor by justly interpreting the scope and credibility of future waste legislation targets. The equitable answer need as well to consider the future development of more energy efficient supply structures for the provision of space heating and domestic hot water in European buildings. If this development is to be characterised by a comprehensive and continued expansion of district 
heating systems (mainly in urban areas), as outlined and discussed amongst others in [31-34] and modelled inter alia in [35-37], the European community will have gained additional access to necessary infrastructures by which to facilitate heat recoveries from waste designated to energy recovery.

Such a development, however, is by no means given for Europe of tomorrow, despite ambitious legislation to bring forth national heating and cooling plans, heat and cold synergy mapping, and improved structural energy efficiency, as mediated inter alia in the Energy Efficiency Directive of 2012 [38, 39]. As will be discussed further in this paper, European district heating has, on average, evolved markedly in absolute terms during the last 20 years, especially so in commercial and public service sectors, but not significantly so in relative terms - and not coherently so in terms of geographical distribution. This latter circumstance itself has an indirect influence on future prospects for heat recovery from waste since a continued disproportionate distribution of heat recovery infrastructures may reflect in an as well skewed distribution of efficient WTE facilities, hereby perhaps intensifying an already untenable situation of continental exports and imports of waste. Possible magnitudes of future European heat recoveries from WTE activities must therefore be conceived as a consequence of several prospective developments, where e.g. behavioural, demographical, economic, political, but, not least, infrastructural dimensions of society all appear significant.

The main aim of this paper is to add perspective and some clarity as to what can be expected of European heat recovery from waste in the future, mainly by illustrating the historic development and plausible future progress of MSW generation, MSW management, and district heating deployment in Europe, as well as to discuss some contextual concerns and issues. As with all complex matters, characterised by multiple influences and mutual 
118 interdependencies, of which seldom all are identifiable and perhaps even less so quantifiable,

119 it is appropriate first to outline an initial general overview. The purpose of this study is 120 essentially to establish such a holistic understanding at EU MS level, hence principally devoting

121 little or no attention to local-, technology-, or regional policy-specific issues undoubtedly

122 related to the continental scope topics at hand. The structural nature of the questions raised

123 in this study is rather; what general tendencies are observable in past records? What are

124 current MS national and EU continental state of affairs? What can be expected in the future,

125 given these historic trends, current conditions, model predictions, and outspoken ambitions

126 for the years to come? More specifically, this paper aims to answer the following three

127 research questions:

128

- What are the historical trends of MSW generation and management among EU MS from 1995 to 2012 ?

- What models have been developed and used in recent years to assess future EU MSW generation and district heating deployment, and what are their predictions for 2030 ?

- According to model predictions and scenario targets, how much MSW is likely to be available for thermal energy conversion and heat recovery in EU district heating systems in $2030 ?$

Given the general uncertainty of future assessments, the answers presented to the latter

138 two of these questions must be interpreted as indicative and approximate only. The purpose 139 here is not claiming to have identified the most likely future development for European waste generation and heat recoveries from these waste flows, a development subject to several 
141 additional sector influences not considered here (e.g. changing characteristics of waste,

142 technical changes and modifications of WTE technologies), but merely to make explicit what 143 past and present modellers have assessed plausible. In this respect, reviewed models and 144 associated assumptions (in the case of regression models, chosen explanatory variables), are 145 viewed and accepted as is, and no model analyses are performed in this context. The study 146 limitations, further, exclude any technical or commercial feasibility assessment of future WTE 147 technologies or heat recoveries from waste in European district heating systems, estimates 148 which despite their general relevance and interest are beyond the study scope and objective. 149 Additional study limitations concern related waste incineration topics, such as ash deposits, 150 air emissions (e.g. greenhouse gases), and issues concerning the production of refuse derived 151 fuels (RDF), as well as waste trade related issues, such as gate fees, public opinion, and 152 economic incentives. Finally, given the immense publication rate within the field of waste 153 management during the last 25 years (a Scopus search 2015-09-15, 1990 to present, returned 1544,369 articles with "waste management" in the paper title!), the literary sources referred to 155 in this work represent a sample reflective of the study objectives rather than constituting a 156 complete review of this ample flow.

\section{Materials and Methods}

159 has hovered at around some 230 to 250 million metric tonnes (Mt) per year (EU28) [40]. For 160 the sake of reference, however, it should be noted that the total sum of all generated waste 161 in EU28, i.e. mineral, metal, animal and vegetal, chemical and medical, textile, glass, plastic, 162 and sludge wastes etc., amounted to no less than 2.51 billion metric tonnes (Bt) in 2012, 
according to [41]. From a perspective of MSW, hence, the annual volumes considered here represents merely one approximate tenth of total generation volumes, and waste destined for energy recovery herein represents itself merely a fraction of total MSW generation. It should also be noted that current heat recoveries from MSW incineration represent less than $10 \%$ of total heat supplies to European district heating systems, which are dominated by natural gas, other bituminous coal, and primary solid biofuels.

At current, if neglecting anaerobe digestion processes, European energy recovery from WTE activities is more or less solely performed by Rankine steam cycle incineration processes, where waste is - either directly or by co-firing - burnt to generate steam and hot flue gases. Gasification of waste, associated with both pros and cons compared to incineration, e.g. an intermediate product (syngas) with a wider array of applications (e.g. fuel production), potential for higher conversion efficiency (e.g. integrated gasifier combined cycles), but syngas being toxic and potentially explosive [42], has so far seen very limited commercial use in Europe. For the future, however, gasification (and pyrolysis) of waste may very well become a challenger in European WTE, considering additional benefits such as reduced generation of pollutants (dioxins and $\mathrm{NO}_{\mathrm{x}}$ ), lower operation temperatures, and more efficient material recovery, e.g. metals [43-45].

Consisting in essence of incineration facilities only then, the stock of designated EU WTE plants currently in operation (2011) was assessed in 2013 as a sub-task during the second EU pre-study of the Heat Roadmap Europe project $[46,47]$. As outlined in Fig. 1, this estimation, which aligned all reported EU28 plants in the 2012 ISWA State-of-the-Art Report (397) [48] with georeferenced facilities reported in the European Pollutant Release and Transfer Register [49], while using as well some additional sources [50, 51], identified 432 facilities with 
187 of these facilities was assessed to $\sim 86 \mathrm{Mt}$, and, as can be seen in Fig. 1, the majority of these

188 facilities are located in Central and North-Western EU Members States.

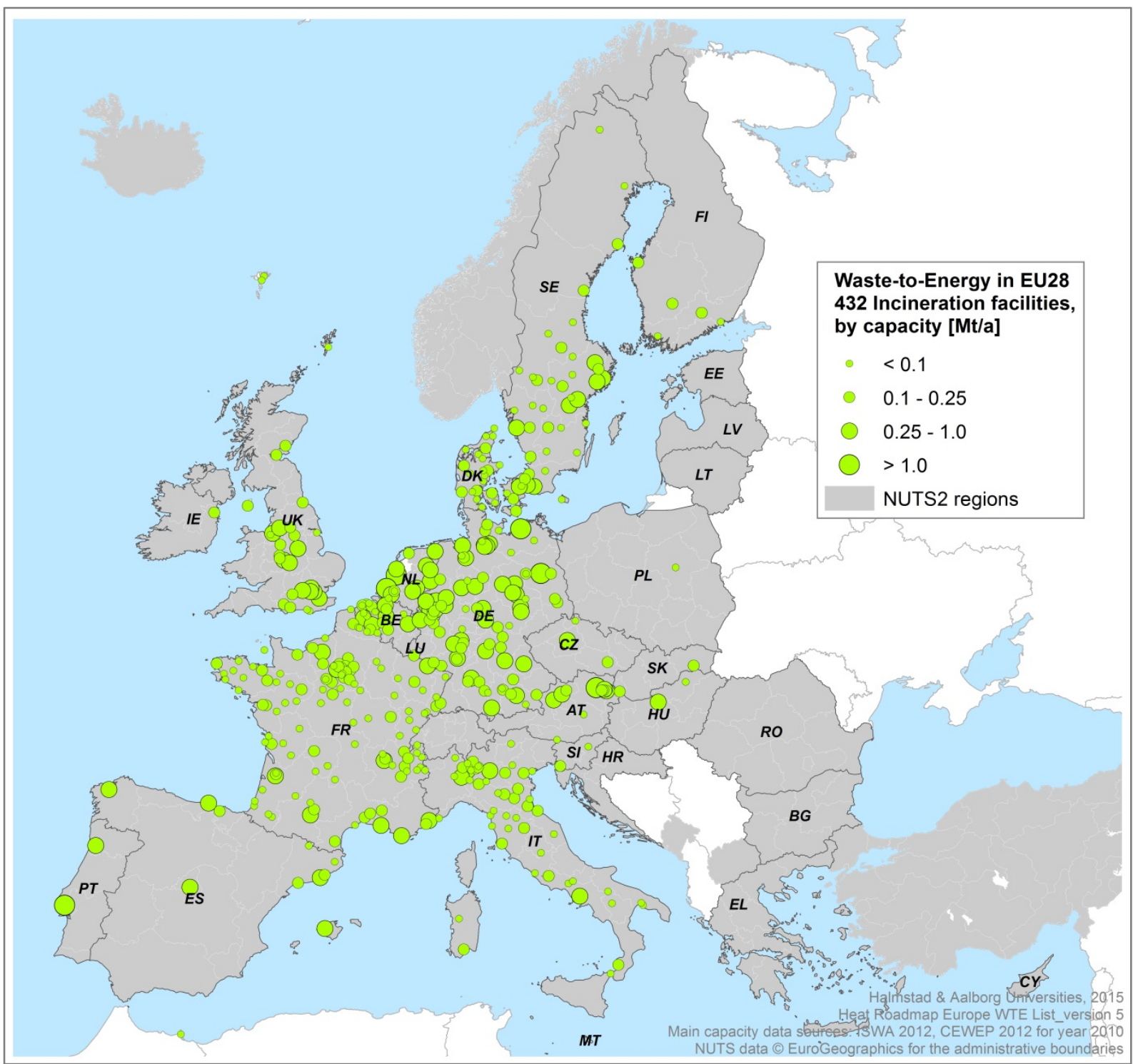

Fig. 1. 432 designated EU28 waste incineration facilities in operation during 2011, by location and by assessed annual capacity. Result from the $2^{\text {nd }}$ European pre-study in the Heat Roadmap Europe project (2013). Sources: 192 [46-51].

As established in the Confederation of European Waste-to-Energy Plants (CEWEP) report

[52], the average energy content of European MSW is $10 \mathrm{GJ} / \mathrm{t}$, expressed as net calorific heat value. If accepting this value as a general conversion factor, the Heat Roadmap Europe 
assessment is well in consonance with 2010 primary energy and energy recovery volumes

197 from waste reported in the extended energy balances of the International Energy Agency 198 (IEA). Herein [53], total primary energy supplies from industrial and municipal (renewable and 199 non-renewable) waste flows destined for energy conversion summed up to $800 \mathrm{PJ}$ in this year, 200 hence equivalent to $80 \mathrm{Mt}$. If neglecting industrial waste (152 PJ), the two fractions of 201 municipal waste represented all together 648 PJ (333 PJ renewable and 315 PJ nonrenewable), which would correspond to some $65 \mathrm{Mt}$ in total under given assumptions. By a municipal waste electricity output of $119 \mathrm{PJ}$ and a heat output of $159 \mathrm{PJ}$, it is fair to anticipate an average overall conversion efficiency of $43 \%$ and a heat recovery efficiency of $159 \mathrm{PJ} / 648$ $\mathrm{PJ}=0.245 \approx 25 \%$ from EU MSW incineration (quota of recovered heat and primary input, see

$[32,36]$ for further references).

And the concept of conversion efficiency truly lies at the heart of European WTE today, since the R1 formula (a performance indicator of waste incineration facilities), was introduced in the Waste Framework Directive in 2008. Taking into consideration both electricity and heat output from WTE conversions, and accentuating generated electricity by a factor 2.6 (and generated heat by a factor 1.1), the total energy yield is weighted against the energy content of the combusted waste [54]. By this regulation it has become possible for efficient WTE plants 213 to be classified as "energy recovery" operations (R1) rather than "waste disposal" activities 214 (D10), by achieving an efficiency higher than 0.6 (for plants in operation before 2009-01-01) 215 and higher than 0.65 (after 2008-12-31). In 2009, around 66\% of European WTE plants were 216 classified as recovery plants, according to the formula [52], and among multiple benefits for 217 these facilities can be mentioned e.g. lower taxes, access to imported waste (without violation 218 of proximity and self-sufficiency principles), and eased admission to bank finance [55]. Albeit 
219 the pronounced promotion of generated electricity, and as well allowance to include some 220 on-site used energy output in the calculation, achieving the R1 efficiency factor is more viable

221 if having cogeneration options available compared to electricity only generation.

\section{$222 \quad 2.1$ Past and current waste generation and management}

223 The data used to assess historic developments and current conditions in this study are all

224 publicly available statistics from Eurostat. These include time series data from 1995 to 2012 on EU MS MSW generation and management [40] and national and NUTS2 regional total population counts [56]. On NUTS2 regional level, corresponding MSW generation data has been made partly available by a promising - however yet to reach full continental stretch pilot project covering the years from 2000 to 2011 [57], which also comprises precious data on number and capacities of recovery and disposal facilities at this regional level [58].

231 illustrated in Fig. 2. This figure is similar in arrangement to the 2008 projection presented by 232 Persson and Werner in 2012 [59], and by comparison it can be observed that average EU MSW 233 per-capita volumes has decreased from approximately $520 \mathrm{~kg} /$ capita (EU27, 2008) to 475 $234 \mathrm{~kg} /$ capita (EU28) during these five years. In terms of waste management, however, landfilling 235 still constitutes the largest treatment option share in relative terms (34\%), but it is noteworthy 236 that the corresponding share was $40 \%$ in 2008. 


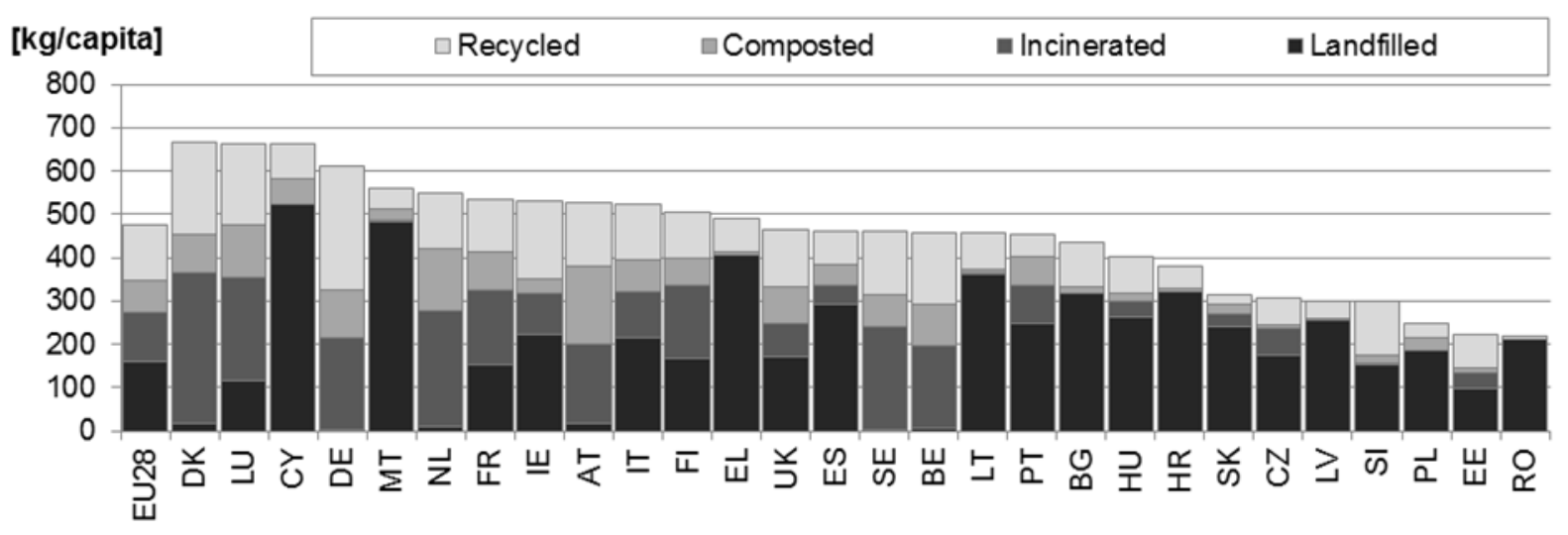

Fig. 2. Distribution of municipal solid waste treatment in EU28 Member States in 2012, by waste hierarchy order categories. Source: $[40,56]$.

\subsection{Future waste generation and model scenarios}

To facilitate an assessment of future European MSW generation and management, mainly so for the year 2030, a literature review was performed by which to learn more about what typical approaches, models, and projections, have been conceived and developed in a devotion to this purpose during recent years. Dating back to the early 1990s, aggregated US industry sector waste generation was modelled by Ayres et al. $[60,61]$ using material balances, a methodological approach attentive of the mass difference between commodity inputs (materials, substances etc.) and corresponding commodity outputs from considered sectors (see also the Leontief input-output economic model [62]). Simultaneously, in Europe, extending from the input-output approach, general equilibrium model applications by, for example, Alfsen et al. [63, 64] and Conrad [65], embraced environmental, emission, and energy system dimensions into the modelling (hence considerably widening the analytical scope), a discourse essentially originating in earlier works of e.g. Johansen [66, 67], Edmonds and Reilly [68, 69], and others [70-73].

In 1997, a novel study by Bruvoll and Ibenholt [74], targeting Norwegian manufacturing industry, presented national projections of solid waste generation by use of a macroeconomic 
model, i.e. a computational multi-sectoral equilibrium model. Considering aspects such as

258

259 technological change, price substitution (value of resources vs labour), and other key economic variables, they anticipated a total 64\% increase of waste generation between 1994 and 2010. In Sweden, computational general equilibrium models were later developed and used by Östblom et al. [75-77], principally based on assuming direct linkage between waste generation and economic activity of firms and households; future waste generation hence being reflected in economic growth and the relative use of production factors. This approach, the so-called EMEC model, was also used by the Swedish Environmental Research Institute (IVL) in 2010 to model future national waste generation volumes in 26 industrial sectors, the public sector, and in Swedish households [78].

Still within, and inherently rooted to, classical economic theories, another generation of models adhered to the principal idea of relating waste generation to e.g. economic activity and population growth, but, as they utilise econometrics, with a conceptually different methodological approach. Statistical investigations and models, by means of simple or multiple regression analysis, characterised this new vein of European studies emerging in the

272 early 2000 s - and especially so constant elasticity models, characterised by generating relative 273 parameters and outcomes [79]. Through a series of reports and book chapters [80-82], the

274 Copenhagen based European Topic Centre (ETC) developed and presented, in 2007, an 275 econometric European model for waste and material flows [83], later also used to produce 276 EU27 MSW generation and treatment predictions for 2020; the ETC 2008 [84] and ETC 2011 277 [85] projections.

278 By 2014, after an institutional name change to the Copenhagen Research Institute, the 279 ETC model was incorporated in the mass flow module of the "European Reference Model on 
281 the European Environment Agency (EEA) [86, 87]. This model (hereafter referred to as the "EU

282 Ref. model"), projects EU28 MSW waste generation up to year 2030 and is structured as a set

283 of operational modules considering a wide range of influential conditions (e.g. prevention,

284 collection, employment, financial costs, environmental impact etc.). A thematic overview of

285 notable model approaches reviewed in this paper are presented in Table 1, which also includes

286 the 2010 Arcadis/Eunomia bio-waste projection for EU27 up to year 2020 (including as well a

287 projection of total MSW generation by this year) [88].

Table 1. Examples of notable waste generation model approaches developed and used during the period 1994 to 2014, by principal model type, flow, and projection year

\begin{tabular}{lcccccc} 
Author/Name & Published & Model type & Flow & Target & Year & Reference(s) \\
\hline Ayres et al. & 1994 & Input/Output & Ind. & USA & - & {$[60,61]$} \\
Bruvoll \& Ibenholt & $1997-2003$ & Gen. equilibrium & Ind. & Norway & 2010 & {$[74,89]$} \\
Östblom et al. & $2006-2010$ & Gen. equilibrium & Ind./MSW & Sweden & 2030 & {$[75-77]$} \\
Sundquist et al. & 2010 & Gen. equilibrium & Ind./MSW & Sweden & 2030 & {$[78]$} \\
Møller Andersen et al. & $2005-2011$ & Econometrics & MSW & EU27 & 2020 & {$[80-85]$} \\
Arcadis/Eunomia & 2010 & Mathematical & MSW & EU27 & 2020 & {$[88]$} \\
EU Ref. model & 2014 & Econometrics/Modules & MSW & EU28 & 2030 & {$[86]$} \\
\hline
\end{tabular}

As the most recent, comprehensive, and only EU model assessment extending to 2030,

the EU Ref. model is used in this work as the key benchmark trajectory by which to evaluate

plausible prospects for future European heat recovery from waste. Appropriately, for this aim,

294 the baseline and five scenario projections elaborated in the model [86], as tabulated in Table

2952 , provide a suitable framework for the study analysis. Current legislation, i.e. the Waste

296 Framework Directive, stipulates a 50\% recycling, or preparation for re-use, target for EU MS

297 by 2020, and, correspondingly, the majority of MS shall have accomplished a 35\% landfill limit

298 by 2016 according to the Landfill Directive. It is likely that current revisions of these regulations

299 will propose much more stringent targets; perhaps as high as $80 \%$ recycling shares and

300 complete landfill bans for all recyclable and biologically degradable wastes. Given these 
301

landfill limit by 2030 (highest ambition level), constitute the reference case used here.

Table 2. Baseline (Business-as-Usual) and five scenarios evaluated by the EU Ref. model on waste generation and management, 2014. Sources: $[20,22,86,90]$

\begin{tabular}{|c|c|c|c|c|}
\hline & Description & $\begin{array}{c}\text { Recycling/Preparation } \\
\text { for reuse target }\end{array}$ & $\begin{array}{l}\text { Landfill } \\
\text { limit }\end{array}$ & By year \\
\hline Baseline & Steady state waste management & - & - & - \\
\hline Scenario 1 & Full implementation of existing targets & $50 \%^{a}$ & $35 \%$ b & $2020 / 2016$ \\
\hline Scenario 2.1 & Increased recycling, no limit on landfill & $60 \%$ & - & 2030 \\
\hline Scenario 2.2 & Further increased recycling, no limit on landfill & $70 \%$ & - & 2030 \\
\hline Scenario 3 & Full implementation of existing targets, landfill limit & $50 \%{ }^{a}$ & $5 \%$ & $2020 / 2030$ \\
\hline Scenario 4 & Further increased recycling, landfill limit & $70 \%$ & $5 \%$ & 2030 \\
\hline
\end{tabular}

a Referring mainly to household waste as expressed in the Waste Framework Directive.

${ }^{b}$ Referring to biodegradable municipal waste fractions as expressed in the Landfill Directive. For MS that had $>80 \%$ landfilling in 1995 , the target year is extended to 2020 .

\subsection{European district heating}

Until recently, there have been very few continental assessments regarding number, distribution, and energy magnitudes of European district heating systems. In 2006, the

317 decrease - in absolute terms - during the time span considered. In the case of number and

318 distribution, it has been apprehended during the development of the Halmstad University

319 District Heating and Cooling database [92] that some 6000 systems currently are in operation

320 (see also [91]), and that these systems are fairly wide spread among MS (for a map on

321 geographical locations of EU district heating systems, see [36]). 
More recently, as detailed in e.g. $[32,93]$, district heating has been anticipated to

323 represent $\sim 12 \%$ of the EU residential and service sector heat market (still heavily dominated

324 by fossil fuels, e.g. natural gas), and consisted of 1.6 EJ out of a total final heat demand of

$32513.1 \mathrm{EJ}$ in 2010, according to the up-to-date Stratego assessment [37]. The winter season in

326 2010, however, was considerably colder than an average year, why a weather-corrected

327 comparison of 1995 and 2012 data was performed. Assuming, as in [91], that reported heat

328 sales in the IEA energy balances [94] represent district heat deliveries, and by use of Eurostat

329 reported heating degree-day statistics for the time period 1980 to 2009 [95-97], a more

330 comparable assessment of EU28 and MS district heating developments is presented in Table

3313 . In relative terms, and keeping in mind some minor deviances in terms of MS heating degree-

332 day calculation practices, EU district heating has on average expanded by $20 \%$ during the

333 considered time-period, especially so in service sectors, albeit with large national variations.

334 Since some constituents of the heat demand (domestic hot water and industrial process heat)

335 are weather independent (not compensated for here), this comparison serves however

336 merely an indicatory purpose. Noteworthy, the average drop in heating degree-days has been

$337 \quad$ 16-18 units per year since 1980.

338

339

340

341

342

343 
Table 3. Weather corrected district heat deliveries to residential, service and industrial sector buildings in 1995 and 2012, by EU28 Member States. Energy volumes in [PJ/a]. Sources: [94-97]

\begin{tabular}{|c|c|c|c|c|c|c|c|c|c|c|c|c|c|c|c|}
\hline \multirow[b]{2}{*}{ MS } & \multirow[b]{2}{*}{$\operatorname{HDD}_{A}{ }^{a}$} & \multicolumn{5}{|c|}{1995} & \multicolumn{5}{|c|}{2012} & \multicolumn{4}{|c|}{ Difference [\%] } \\
\hline & & $f_{H D D}{ }^{b}$ & $\operatorname{Res}^{c}$ & Ser & Ind $^{d}$ & Tot & $f_{H D D}{ }^{e}$ & $\operatorname{Res}^{c}$ & Ser & Ind $^{d}$ & Tot & Res & Ser & Ind & Tot \\
\hline AT & 3,540 & 0.98 & 15 & 15 & 4 & 34 & 1.08 & 37 & 32 & 13 & 82 & 141 & 119 & 192 & 138 \\
\hline $\mathrm{BE}$ & 2,830 & 1.04 & 0.9 & 0.6 & 8 & 10 & 1.13 & 2 & 4 & 24 & 30 & 130 & 671 & 187 & 210 \\
\hline BG & 2,654 & 0.97 & 31 & 1 & 80 & 112 & 1.07 & 16 & 4 & 23 & 44 & -47 & 268 & -71 & -61 \\
\hline CY & 762 & 0.90 & 0 & 0 & 0 & 0 & 1.17 & 0 & 0 & 0 & 0 & - & - & - & - \\
\hline$C Z$ & 3,533 & 0.98 & 41 & 18 & 91 & 150 & 1.09 & 47 & 20 & 29 & 96 & 14 & 10 & -68 & -36 \\
\hline $\mathrm{DE}$ & 3,199 & 0.98 & 291 & 0 & 69 & 360 & 1.10 & 156 & 89 & 234 & 478 & -46 & - & 238 & 33 \\
\hline DK & 3,438 & 0.97 & 59 & 26 & 4 & 89 & 1.13 & 78 & 36 & 5 & 120 & 32 & 42 & 18 & 34 \\
\hline $\mathrm{EE}$ & 4,393 & 1.04 & 23 & 1 & 2 & 26 & 1.08 & 15 & 5 & 2 & 22 & -32 & 264 & -8 & -14 \\
\hline EL & 1,642 & 1.00 & 0 & 0 & 0 & 0 & 1.09 & 2 & 0 & 0 & 2 & - & - & - & - \\
\hline ES & 1,831 & 1.20 & 0 & 0 & 0 & 0 & 1.09 & 0 & 0 & 0 & 0 & - & - & - & - \\
\hline $\mathrm{FI}$ & 5,774 & 1.02 & 82 & 0 & 9 & 91 & 1.09 & 124 & 0 & 71 & 195 & 52 & - & 655 & 115 \\
\hline$F R$ & 2,459 & 1.03 & 24 & 0 & 0 & 24 & 1.11 & 75 & 34 & 8 & 116 & 214 & - & - & 389 \\
\hline HR & 2,561 & 0.96 & 5 & 0.8 & 4 & 10 & 1.11 & 6 & 2 & 2 & 11 & 17 & 117 & -37 & 5 \\
\hline HU & 2,886 & 1.00 & 32 & 17 & 5 & 54 & 1.08 & 24 & 7 & 14 & 45 & -25 & -61 & 205 & -17 \\
\hline IE & 2,871 & 1.07 & 0 & 0 & 0 & 0 & 1.12 & 0 & 0 & 0 & 0 & - & - & - & - \\
\hline IT & 1,949 & 1.01 & 0 & 0 & 0 & 0 & 1.15 & 35 & 5 & 124 & 164 & - & - & - & - \\
\hline LT & 4,048 & 1.02 & 35 & 8 & 7 & 51 & 1.08 & 22 & 9 & 10 & 41 & -36 & 8 & 31 & -19 \\
\hline LU & 3,164 & 1.01 & 0 & 0 & 0 & 0 & 1.13 & 0 & 3 & 1 & 3 & - & - & - & - \\
\hline LV & 4,220 & 1.03 & 26 & 11 & 2 & 39 & 1.08 & 17 & 6 & 0.3 & 24 & -33 & -42 & -86 & -38 \\
\hline MT & 543 & 1.21 & 0 & 0 & 0 & 0 & 1.40 & 0 & 0 & 0.1 & 0.1 & - & - & - & - \\
\hline $\mathrm{NL}$ & 2,854 & 1.01 & 7 & 12 & 55 & 74 & 1.14 & 12 & 24 & 51 & 87 & 71 & 107 & -9 & 17 \\
\hline PL & 3,574 & 0.99 & 263 & 23 & 77 & 363 & 1.08 & 195 & 43 & 32 & 269 & -26 & 89 & -59 & -26 \\
\hline PT & 1,278 & 1.39 & 0 & 0 & 2 & 2 & 1.09 & 0.3 & 1 & 15 & 16 & - & - & 588 & 645 \\
\hline RO & 3,092 & 0.98 & 131 & 0 & 51 & 183 & 1.08 & 43 & 11 & 13 & 66 & -67 & - & -75 & -64 \\
\hline SE & 5,387 & 0.98 & 80 & 51 & 14 & 145 & 1.09 & 125 & 62 & 19 & 205 & 56 & 22 & 30 & 41 \\
\hline SI & 3,024 & 0.99 & 4 & 4 & 1 & 9 & 1.09 & 4 & 2 & 2 & 8 & -2.8 & -42 & 109 & -3.7 \\
\hline SK & 3,416 & 1.00 & 16 & 12 & 1 & 29 & 1.08 & 22 & 6 & 7 & 34 & 33 & -53 & 475 & 17 \\
\hline UK & 3,081 & 1.03 & 0 & 0 & 0 & 0 & 1.10 & 2 & 18 & 37 & 57 & - & - & - & - \\
\hline Tot & 3,000 & $0.99^{f}$ & 1,168 & 198 & 488 & $1,854^{\mathrm{g}}$ & $1.10^{f}$ & 1,062 & 421 & 734 & $2,217^{h}$ & -9 & 112 & 50 & 20 \\
\hline
\end{tabular}

a Average annual Heating Degree Days $\left(\mathrm{HDD}_{\mathrm{A}}\right)$ per MS based on 1980 to 2009 time series data reported in [95, 97]

${ }^{b}$ Multiplier, $f_{H D D}$, is the ratio of $H_{D D}$ over actual HDD for the year at hand. $f_{H D D}>1$ indicates a year warmer than the normal year.

${ }^{c}$ Residential sector volumes include Non-specified (other) sector heat.

${ }^{\mathrm{d}}$ Reported industrial heat volumes may include some heat used on-site for internal purposes.

e Multipliers for 2012 established by simple linear regression of MS 1980 to 2009 time series data and extrapolated to this year.

${ }^{\mathrm{f}}$ Total multipliers are fictive (reflecting the sum of MS weather corrected district heat volumes relative the sum of corresponding MS raw data heat volumes) and does not necessarily represent actual EU28 HDD factors for 1995 or 2012.

g Raw data for 1995: 1,874 PJ.

h Raw data for 2012: 2,014 PJ 
In terms of future European district heating deployment levels, no formal targets, as for

waste management, have so far been established. Evidence, however, that district heating could expand cost-effectively by three times compared to current levels (essentially in innercity areas) have been provided in [31], and - partly by this rationale - future expansion levels considering 30\% (2030) and 50\% (2050) shares of the total EU27 residential and service sector heat market have been modelled within the Heat Roadmap Europe context [35]. As perceived herein, the potential for WTE heat recovery in district heating systems was assessed at $330 \mathrm{PJ}$ ( $\sim 33 \mathrm{Mt})$ in 2030 and $585 \mathrm{PJ}$ ( 59 Mt) in 2050. At the current, average, EU28 heat recovery efficiency (25\%), such heat recovery volumes would need to correspond to total MSW volumes designated for energy conversion of approximately $132 \mathrm{Mt}$ and $236 \mathrm{Mt}$, respectively. If, hypothetically, average heat recovery efficiencies were to increase to $30 \%, 40 \%$ or $50 \%$ in the future, corresponding MSW volumes destined for energy conversion would be respectively; 110, 83, and $66 \mathrm{Mt}$ by 2030, and 197, 148, $118 \mathrm{Mt}$ by 2050 .

\section{Results}

The results presented in the following are all based on data, literature, models, and methodological approaches, as described and accounted for above, and further ordered in alignment with the initial research questions asked. Hereby, study results refer firstly to historical and current EU MS MSW generation and treatment volumes from 1995 to 2012, secondly to model predictions of future MSW generation volumes for 2020 and 2030, and thirdly to assessed MSW volumes available for heat recovery in European district heating systems by 2030 . To complement the latter, an arbitrary sensitivity analysis, where the two 
variables; (i) predicted total EU MSW generation in 2030 and (ii) average EU heat recovery

384 efficiency by this year, are allowed to take on alternative values.

\subsection{Waste generation and treatment - 1995 to 2012}

MSW generation in EU27 saw steady annual increases during the late 1990s and marked a thitherto all-time high of $256 \mathrm{Mt}$ in 2002. Succeeded by a temporary decline during 2003 to 2005, new record-breaking generation volumes were once again recorded in 2006 (258 Mt) and 2007 ( $260 \mathrm{Mt})$, to be followed by marginal, but consecutive, annual declines leading up to year 2012 (see Fig. 3, at left). Whether the apparently incessant decrease from 2008 and onwards reflects genuine behavioural (or structural) changes among European citizens and communities (and if so with decisive implications for future generation volumes), is an issue resolvable only at the access of more recent data. It is clear, however, that European efforts to reduce landfilling has been expedient during the considered period; representing a drop from $143 \mathrm{Mt}$ (1995) to $79 \mathrm{Mt}$ (2012). This significant achievement is reflected in corresponding and coherent increases in annual MSW volumes designated for incineration, recycling, and composting. Since Eurostat statistics subdivide incineration volumes in two categories; with energy recovery (R1) and without energy recovery (D10), they provide insight into the distribution of incineration volumes by these two treatment options, see Fig. 3 at centre. Among all treatment categories, WTE with energy recovery represents the fastest growing alternative, indexing above 300 during the considered time interval. 


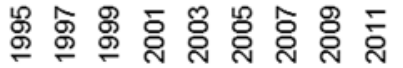

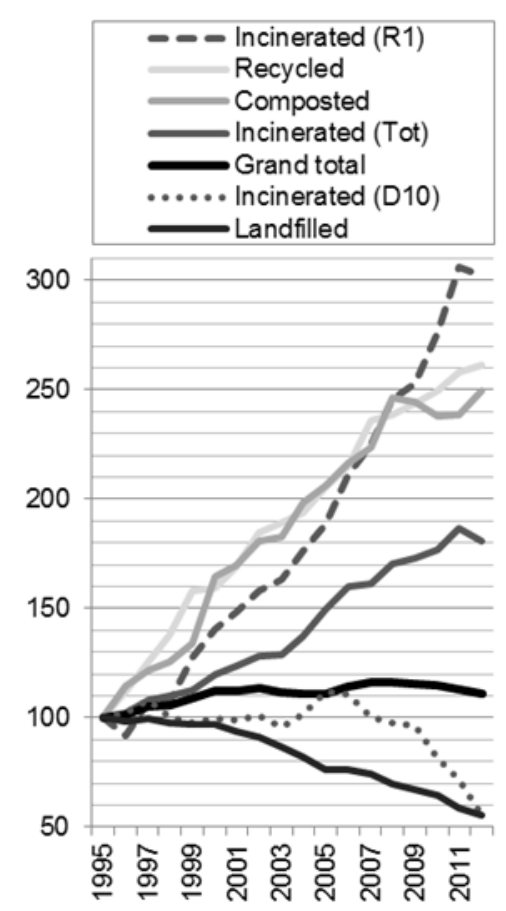

Fig. 3. EU27 MSW generation and management from 1995 to 2012 . At left, total generation, treatment, and category volumes. At centre, indexed developmental trends by category with base year $1995=100$. At right, relative distribution of treatment categories. Source: [40].

As illustrated in Fig. 3, at right, the relative reduction of EU landfilling further corresponds to a 34\% decrease for this treatment option out of total MSW treatment volumes (67\% in 1995 and $33 \%$ in 2012), which effectively confirms an average fulfilment of the Landfill Directive targets for 2016. As for the relative change of MSW volumes incinerated with energy recovery, equivalent shares out of total MSW treatment volumes were 7\% (1995) and 20\% (2012), while total incineration increased from $15 \%$ to $24 \%$. Validation crosschecking of Eurostat reported MSW incineration volumes for 2010 with IEA data [53] identified smaller deviations. Possible explanations might be varying MSW definitions and counting routines among MS and perhaps incineration of MSW in e.g. cement kilns not accounted for in the Eurostat data. While summing up total incineration volumes to $57 \mathrm{Mt}$ (44 Mt with energy recovery and $13 \mathrm{Mt}$ 417 without), the Eurostat data was somewhat lower than the anticipated $65 \mathrm{Mt}$ (648 PJ and by 418 conversion factor of $10 \mathrm{GJ} / \mathrm{t}$ ) reported by the IEA. Since the used Eurostat data includes no 
419 information on generated heat output, hence inhibiting an estimate of heat recovery 420 efficiency, the IEA data was chosen for this purpose.

\section{$421 \quad 3.2$ Waste generation and treatment - in $\mathbf{2 0 3 0}$}

422 The first of four considered model predictions assessing EU MSW generation was the ETC 4232008 projection. As shown in Fig. 4, at left, the trajectory proposed at this stage (projection 424 start year 2005, EU27) anticipated total MSW generation volumes well above 330 Mt by 2020, 425 a probable over-shoot three years later curtailed to approximately $280 \mathrm{Mt}$ in the ETC 2011 426 version (start year 2007). The 2010 assessment of Arcadis/Eunomia arrived at a similar level 427 (270 Mt). As if outlining maximum and minimum conditions, the three 2020 assessments 428 seemingly mark the confines of most plausible developments for 2030 , as the EU Ref. model 429 projection stretches on to a total MSW generation volume of $308 \mathrm{Mt}$ by this year (294 Mt 430 available for management, given a historic $95.6 \%$ average ratio between generation and 431 management in EU27 during 1995 to 2012). 

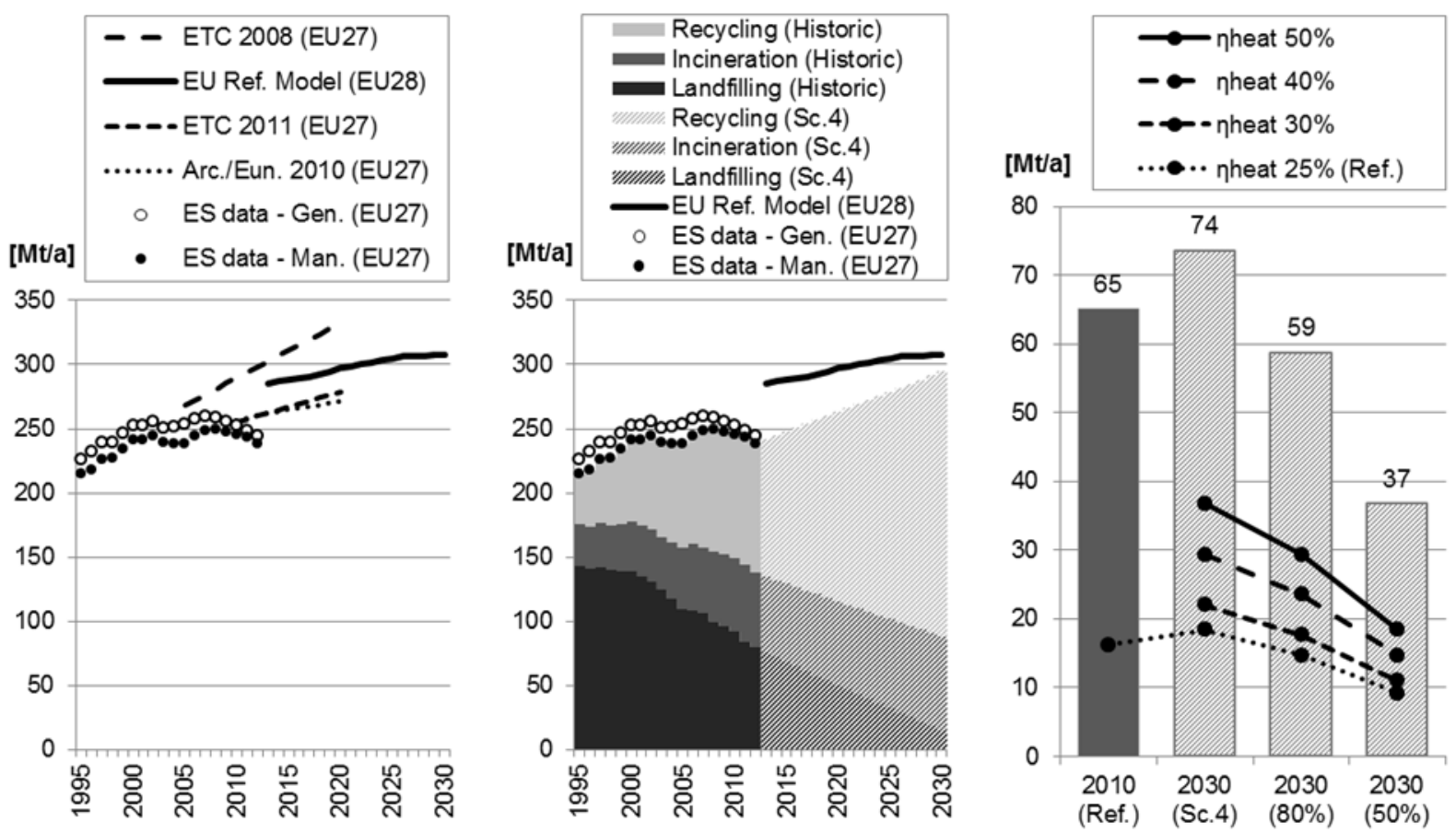

Fig. 4. At left, EU27 MSW generation and management volumes from 1995 to 2012 and four model predictions

of future EU MSW generation. At centre, EU27 MSW volumes by treatment categories from 1995 to 2012 ("Recycling" including composting) linearly interpolated from 2012 to 2030 according the EU Ref. model (Scenario 4). At right, MSW volumes designated for incineration in 2010 and current heat recovery efficiency (reference) compared by sensitivity analysis to the EU Ref. model in 2030 (Scenario 4: 100\%, 80\% and 50\%) and three levels of plausible future EU heat recovery efficiencies. Sources: $[40,53,84-86,88]$.

\subsection{Heat recovery in European district heating systems in $\mathbf{2 0 3 0}$}

If in 2030, the EU Ref. model projections will have proven accurate, approximately $294 \mathrm{Mt}$

443 of MSW will be available for waste management in EU28. If the European community,

444 furthermore, manages to comply with the $4^{\text {th }}$ scenario in the EU Ref. model context, $70 \%$ (206

$445 \mathrm{Mt}$ ) of this manageable MSW volume will be recycled and only 5\% ( 15 Mt) will be landfilled.

446 The remaining $25 \%$, equalling $74 \mathrm{Mt}$ by this year, should consequently be available for energy

447 and heat recovery. Hereby, as presented in Fig. 4, at centre, data based 2012 levels of MSW

448 treatment categories may be linearly interpolated to meet these anticipated 2030 volumes,

449 hence permitting a visual representation and comprehension of the plausible distribution of 
452 (147 Mt) of the model projection, correspondingly less MSW will be available for energy conversions (59 Mt (80\%) and $37 \mathrm{Mt} \mathrm{(50 \% ),} \mathrm{assuming} \mathrm{constant} \mathrm{shares),} \mathrm{as} \mathrm{outlined} \mathrm{in} \mathrm{Fig.} \mathrm{4,} \mathrm{at}$ 454 right. Depending, however, on what average EU heat recovery efficiencies that will have been 455 attained by this year, which itself, in essence, will be determined by materialised levels of 456 future EU district heating deployment, actual heat recovery volumes may increase although 457 available MSW volumes are reduced. If, in 2030, only half of projected MSW volumes will be 458 generated (thereby leaving only $37 \mathrm{Mt}$ to energy conversions), then $184 \mathrm{PJ}$ may still be 459 recovered as heat - given an average EU heat recovery efficiency of 50\% (corresponding to $46018.4 \mathrm{Mt}$ at conversion factor $10 \mathrm{GJ} / \mathrm{t})$.

\section{Discussion}

From this, it is likely that future heat recoveries from waste in European district heating systems will be determined by (at least) two independent processes; (i) the success by which decoupling of human well-being from virgin resource use is materialised, and (ii) forthcoming transition levels towards serial supply structures for the provision of building heat demands.

As for the first of these detached developments, there are today only vague indications that absolute decoupling, i.e. reduced waste generation parallel with continued economic

468 growth, is occurring in the EU context. Mazzanti and Zoboli, who, by non-linear regression 469 modelling (considering as well structural and socio-economic variables), evaluated the EU 470 decoupling progress in 2008, concluded that "for waste generation there is still no absolute 471 delinking trend" [98], see also [99]. In a Swedish study [100], Sjöström and Östblom suggested 472 that, for absolute decoupling by 2030 (start year 2006), waste intensities linked to the three 
473 drivers technical change, economic growth, and household consumption, will need to

474 decrease at a rate twice that of historical reduction rates, which appears not to be the case in 475 contemporary Europe. Some indices, however, of both absolute and relative MS level 476 decoupling of MSW generation relative economic growth, has been reported more recently in 477 [101], in turn referring to [102-104]. Nevertheless, despite marginally more efficient domestic 478 and raw material consumption during 2000 to 2012 (mainly in coincidence with the financial 479 crisis of 2008), as reported in [105], European consumption patterns have in general remained 480 highly resource intensive, which is why continued absolute decoupling must be acknowledged as posing both fundamental and structural challenges for the European community. taxation of resources rather than taxation of labour, proposed by Bruvoll in 1998 [106]), 484 absolute decoupling needs to imply either a shift towards more immaterial consumption, i.e. 485 less resource intensive products and commodities, or a principally new regime in terms of 486 European re-use and recycling. In view of current recycling levels ( $27 \%$ recycling and 15\% 487 composting, totalling at $\sim 42 \%$ in 2012 , see Fig. 3 , at right), a proposition of absolute 488 decoupling of waste generation from economic growth will in itself be contradictious unless 489 supported by the permeate arrangement of effective, operational, and sustainable recycling 490 technologies and infrastructures. It can therefore be assumed that a realisation of current EU 491 decoupling ambitions will require levels of political and economic devotion, of state and 492 municipal commitment, and of collective and individual discipline, intrinsically higher than 493 current ones, and that this needs to be addressed and accompanied by appropriate policy and 494 procurement measures. 
As for the second process, of which much less can be said in terms of expected

developmental progress since no formal targets so far has been set for EU district heating

497 deployment, a transition towards serial supply structures on the European building heat

market is as well associated with considerable economic investment. Moreover, a genuine

499

transition of this kind, i.e. a reform towards improved structural energy efficiency, is likely to have a profound influence on traditional energy system perceptions, as well as on a wide array of technical, industrial, social, and infrastructural dimensions. In relation to WTE conversions, given their appropriate application, waste incineration with heat recovery in district heating systems is likely to represent, also in ambitious recycling and circular economy contexts, a necessary, multifunctional technology solution by which to bridge and enhance resource and energy efficiency improvements. The peculiar circumstance that (non-recyclable) combustible 506 waste fractions, simultaneously being both a burden and an asset (residue and fuel), find their 507 most rewarding application in such WTE conversions needs to be kept in mind when 508 formulating future EU waste management and energy system policies.

In a recent European study by Sundberg [107], asking what role energy recovery will have

510 in the context of increased material recycling, main conclusions are that continued access to 511 WTE facilities are essential also at high recycling rates; namely by the ability to treat 512 deteriorated combustible residues inevitably extending from recycling processes. 513 Additionally, let aside generation of electricity and heat, incineration (and gasification) 514 processes make viable the extraction of metals contained in the original waste flow, as well as 515 the destruction of contaminated and non-recyclable fractions - all eventually contributing to 516 a reduced demand for landfill deposits. Another key message from Sundberg, also illustrated 517 in Fig. 2, is that MS with lowest landfilling rates at current; all have highest levels of both 
518 recycling and incineration (e.g. $\mathrm{AT}, \mathrm{BE}, \mathrm{DE}, \mathrm{DK}, \mathrm{NL}$, and $\mathrm{SE}$ ). It is clear, however, that waste

519 incineration processes without heat recovery, not to mention without energy recovery all

520 together, imply significantly reduced synergetic qualities of the respective treatment

521 operations performed. To illustrate this further, see Fig. 5 (similar in arrangement to the 2008

522 projection presented by Persson and Werner in [108]), average 2012 EU28 MS heat recovery

523 and absorption (electricity) efficiencies from all non-recycled MSW fractions (i.e. both

524 incineration and landfill volumes) are depicted together with EU28 average values.

525

526

527

528

529

530

531

532

533

534

535

536

537

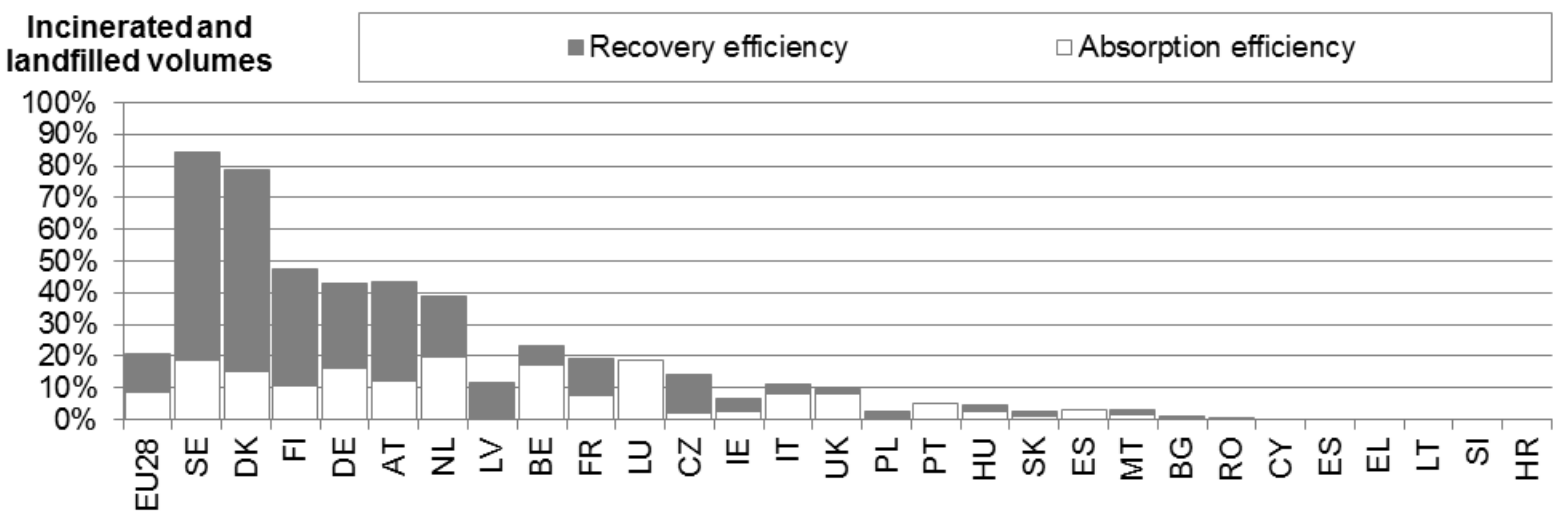

Fig. 5. Distribution of recovery and absorption efficiencies for incinerated and landfilled (non-recycled) volumes of MSW in EU28 Member States during 2012. Sources: [40, 53]. Absorption efficiency is equal to electrical efficiency.

The Eurostat data [40] used in Fig. 5 corresponded to $58.1 \mathrm{Mt}$ (incineration) and $80.7 \mathrm{Mt}$ (landfilling) in 2012, hence totalling at $139 \mathrm{Mt}$ in this year. At the used study conversion factor of $10 \mathrm{GJ} / \mathrm{t}$, this would then correspond to energy magnitudes of approximately $0.58 \mathrm{EJ}$ and $0.81 \mathrm{EJ}$, respectively, revealing a total $1.39 \mathrm{EJ}$ of energy embedded in these waste fractions. After cross-referencing with IEA data for the same year [53], the total energy content was eventually corrected to $1.51 \mathrm{EJ}$. By reference to this total volume, the $0.13 \mathrm{EJ}$ of generated electricity rendered an absorption efficiency of $9 \%$ and the total heat output of 0.19 EJ (sum of reported heat output from energy sector activities (0.17 EJ) and additional MSW heat output in total final consumption outside the industry sector (0.02 EJ)) rendered an average 
538 EU28 heat recovery efficiency of 12\%. From this, an average overall conversion efficiency of 539 only $21 \%$ from European MSW fractions currently not recycled or composted indicates that $54079 \%(1.19 \mathrm{EJ})$ of the total energy content remained unharvested during this year. Thus, it is 541 fair to conclude that more energy can be recovered from current EU MSW not recycled, mainly 542 by redirection of current landfill volumes, and that installation of more incineration capacity, 543 as well as retrofitting of existing units, seems generally viable.

544 Another decisive aspect to consider in this respect, perhaps also representing a third 545 independent process to monitor, concerns the geographical distribution of current 546 incineration capacities, which by use of pilot project Eurostat data on NUTS2 level is visualised 547 in Fig. $6[56,58]$. Concerning installed R1 capacity (which notably is summed up to a staggering $548149.6 \mathrm{Mt}$ in this dataset, not commented further here) this map illustrates the current 549 distribution of recovery capacity in Europe by normalisation to regional population counts and 550 referring to an anticipated EU28 average ratio 0.3 by relating to the abovementioned total 551 capacity). Since, in practice, a more even distribution of R1 capacities is achievable mainly by 552 increased access to local heat distribution infrastructures, this image indeed underlines the 553 need to expand European district heating if to obtain spatially coherent heat recoveries from 554 present and future WTE conversions. 


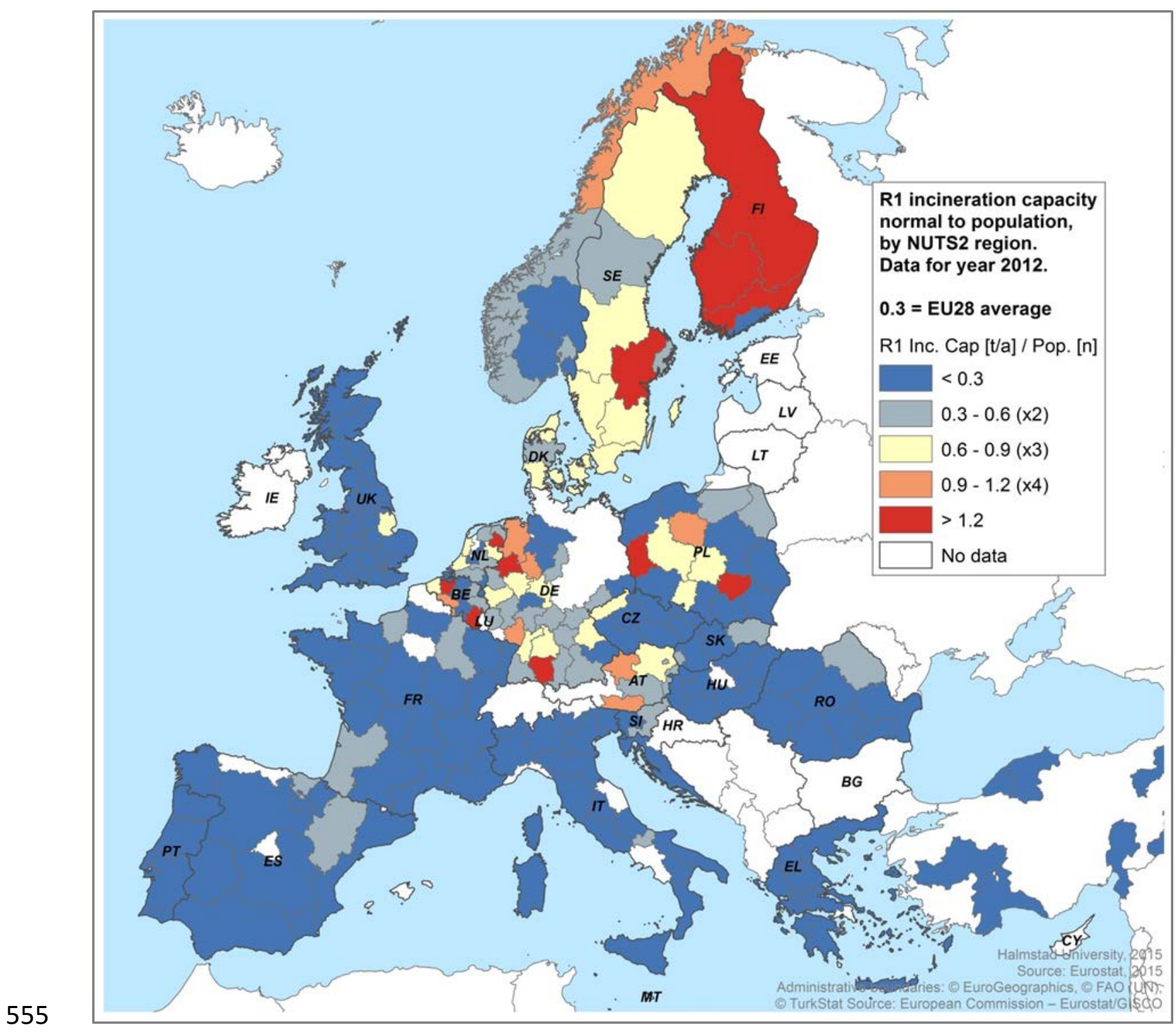

556 Fig. 6. R1 incineration capacity per NUTS2 region, normal to population. Average EU28 value established as ratio of reported total $\mathrm{R} 1$ capacity $(149.6 \mathrm{Mt})$ and total EU28 population in 2012. Sources: [56, 58].

Additionally, contextual developmental trends such as demographically expressed in

migrations and urbanisation, do in themselves influence future European waste management

conditions. According to used study data, including time series of regional population counts

561 from 1990 to 2014 [56], clear indications of population movements mainly from former east-

562 European MS westward, and as well continued urbanisation processes in practically all large

563 urban zones, should constitute useful information in the construction of future European

564 waste management structures. It is noteworthy, since urban areas represents most beneficial 
565

566

567 568

569 illustrative of the many approaches and preferences plausible, current waste imports and 570 exports may reversely be viewed as a potent means by which to achieve a faster reduction of

571 current landfill volumes, as discussed amongst others in [109], which may serve here as a final 572 example of the general complexity characterising European waste management.

\section{Conclusions}

To conclude, in this paper a literature and data review has been presented by which to 575 answer three initial research questions concerning current and future prospects for heat 576 recovery from waste in European district heating systems. The study has focused on MSW in

577 the EU context with the purpose to identify aggregated general tendencies and trends by 578 which to assess plausible future developments for EU waste generation and management. The 579 main and overarching conclusion is that efficient, i.e. recovery classed WTE conversions (as 580 defined by the R1 formula), in principal requires access to heat distribution infrastructures by 581 which to utilise recovered excess heat. In this respect, current and future deployment levels 582 of district heating systems throughout the European continent are and will be directly 583 reflected in the geographical distribution and spatial spread of efficient waste incineration 584 capacity. For obvious reasons, therefore, EU waste management policies should align and 585 interact to a considerable degree with corresponding energy system related regulations and 586 concerns. 
As for the first dedicated research question, historical trends of MSW generation and management among EU MS from 1995 to 2012 reveal, on average, clear evidence of markedly 589 reduced annual volumes designated for landfilling, effectively reflected in increasing corresponding shares for recovery incineration, recycling, and composting, respectively. On

MS level, however, landfilling is still excessive in some instances and one third of all generated not exploited, this practise is associated with greenhouse gas emissions and stress on local ecosystems. It is further observable, that MS which have successfully implemented waste 595 management routines including all non-landfilling option, i.e. recycling, composting, and 596 recovery incineration, also have lowest landfilling volumes. Additionally, WTE incineration 597 with heat recovery has increased three-fold during the considered period in terms of energy 598 volumes, but recovery capacity is poorly distributed over the European continent.

599 For the second research question, the study answer is that several different models and 600 approaches have been developed and used in recent years to assess future EU MSW 601 generation and, to a lesser extent, to estimate future deployment levels of European district 602 heating. Originating principally in classical economics, be they characterised by material 603 balances (input/output), multi-sectoral equilibrium models, or statistical econometric 604 approaches, four up-to-date MSW model predictions targeting the EU were selected during 605 the review process. While data leading up to 2012 indicate continuously reduced total MSW 606 generation volumes in Europe, as to which the influence of the financial crisis in 2008 - or 607 perhaps a genuine behavioural shift in consumption patterns - is too early to determine 608 statistically, all considered models predict increased MSW generation volumes for the years 609 to come. The most recent of these, the EU Ref. model, being the only one extending to 2030, 
610 foresees a total MSW generation volume of $308 \mathrm{Mt}$ by this year, which, by a historical average

611 ratio between generation and treatment volumes, should correspond to some $294 \mathrm{Mt}$ 612 available for waste management options. Through the availability of regional waste data in 613 later years, future modelling approaches should benefit from applications such as 614 geographically weighted regression analysis and other contemporary Geographical 615 Information Systems (GIS) applications.

616 Thirdly, based upon the most ambitious and stringent of five scenarios for 2030 617 elaborated in the context of the EU Ref. model, stipulating $70 \%$ recycling and a $5 \%$ landfill limit 618 by this year, the study results suggest that the remaining one-quarter could be conceived as 619 available for energy recovery. The key conclusion in this respect, however, is not what exact 620 magnitudes of MSW that will be available for thermal energy conversion in a given year, but 621 rather at what heat recovery efficiencies that available waste volumes will be harnessed in 622 forthcoming WTE conversions. Depending thus, in a deeper sense, on the transitional progress 623 towards more efficient supply structures on future European heat markets (key features in 624 smart energy systems), the presence of local heat distribution infrastructures, as conceived 625 here, is an equally determinant factor as that of total generation volumes regarding prospects 626 for future heat recoveries from waste.

627 Hereby, district heating systems represent an important infrastructural technology, 628 essential for not only providing energy and environmentally efficient heat supplies to 629 residential, service, and industry sectors, but also for facilitating increased total conversion 630 efficiencies of WTE plants. In such contexts, energy recovery from waste, itself then a driver 631 for future district heating deployment in Europe, represents an enabling technology whereby 632 to achieve improved energy system efficiency while simultaneously reducing the demand for 
633 landfilling and deposits, again reminding us of the synergetic opportunities inherent to WTE 634 system technologies.

\section{Acknowledgements}

636 The work presented in this paper is a result of the research activities of the Strategic 637 Research Centre for 4th Generation District Heating (4DH), which has received funding from 638 The Innovation Fund Denmark. The study was performed under WP2 and initiated as item 19 639 in the $2014 / 2015$ work programme. The authors also wish to extend their grateful thanks to 640 professor Frits Møller Andersen at the Technical University of Denmark for two interviews 641 during the spring of 2015. 


\section{References}

643 [1] EC. Environment: Waste. European Commission. 2015. Web page available at (2015-09-04):

644 (http://ec.europa.eu/environment/waste/).

645 [2] Sedee C, Jantzen J, de Haan BJ, Pearce DW, Howarth A. Technical Report on Waste Management.

646 RIVM report 481505017. Environment Directorate-General of the European Commission. RIVM,

647 Bilthoven. 2000.

648 [3] GreenChoices. Waste recycling: Environmental impacts. Green Choices, Gloucestershire. 2015.

649 Web page available at (2015-09-04): (http://www.greenchoices.org/green-living/waste-

650 recycling/environmental-impacts).

651 [4] FullCycle. Green by Nature: What is waste and why is it a problem? Full Cycle. 2009. Web page

652 available at (2015-09-04): (http://www.fullcycle.co.za/index.php/what-is-waste-and-why-is-it-a-

653 problem.html).

654 [5] EC. Research \& Innovation. Environmental Research Policy. Framework Programmes for Research.

655 European Commission. 2015. Web page available (2015-09-10):

656 (https://ec.europa.eu/research/environment/policy/article_1437_en.htm).

657 [6] EU. Decision No 1386/2013/EU of 20 November 2013 on a General Union Environment Action

658 Programme to 2020 'Living well, within the limits of our planet'. Brussels: European Parliament and 659 the Council; 2013.

660 [7] EU. Directive 94/62/EC of 20 December 1994 on packaging and packaging waste. Brussels:

661 European Parliament and Council Directive; 1994.

662 [8] EU. Directive 2000/53/EC of 18 September 2000 on end-of life vehicles. Brussels: European 663 Parliament and the Council; 2000.

664 [9] EU. Directive 2006/66/EC of 6 September 2006 on batteries and accumulators and waste 665 batteries and accumulators and repealing Directive 91/157/EEC. Brussels: European Parliament and 666 the Council; 2006.

667 [10] EU. Directive 2006/12/EC of 5 April 2006 on waste. Brussels: European Parliament and the 668 Council; 2006.

669 [11] EU. Directive 2012/19/EU of 4 July 2012 on waste electrical and electronic equipment (WEEE).

670 Brussels: European Parliament and the Council; 2012.

671 [12] FORWAST. Overall mapping of physical flows and stocks of resources to forecast waste

672 quantities in Europe and identify life-cycle environmental stakes of waste prevention and recycling.

673 2007. Web page available (2015-09-10): (http://forwast.brgm.fr/).

674 [13] EUWMC. Environment. Sustainable urban waste management (1999 to 2005). European Waste

675 Management Cluster (EUWMC). 2005. Web page available at (2015-09-10):

676 (https://ec.europa.eu/research/environment/print.cfm?file=/comm/research/environment/newsand

677 doc/article_3186_en.htm).

678 [14] Dahlén L, Lagerkvist A. Methods for household waste composition studies. Waste Management. 679 2008;28(7):1100-12.

680 [15] Dahlén L, Vukicevic S, Meijer J-E, Lagerkvist A. Comparison of different collection systems for 681 sorted household waste in Sweden. Waste Management. 2007;27(10):1298-305.

682 [16] Nelles M, Arena U, Bilitewski B. Thermal waste treatment - An essential component of a 683 sustainable waste treatment system. Waste Management. 2010;30(7):1159-60.

684 [17] Burnley SJ. The impact of the European landfill directive on waste management in the United 685 Kingdom. Resources, Conservation and Recycling. 2001;32(3-4):349-58. 
[18] Burnley SJ. A review of municipal solid waste composition in the United Kingdom. Waste 687 Management. 2007;27(10):1274-85.

688 [19] Bruvoll A, Halvorsen B, Nyborg K. Households' recycling efforts. Resources, Conservation and 689 Recycling. 2002;36(4):337-54.

690 [20] EU. Council Directive 1999/31/EC of 26 April 1999 on the landfill of waste. Brussels: European 691 Parliament and the Council; 1999.

692 [21] ES. News release 48/2012 of March 27, 2012. Landfill still accounted for nearly $40 \%$ of municipal 693 waste treated in the EU27 in 2010. Luxembourg: Eurostat; 2012.

694 [22] EU. Directive 2008/98/EC of November 19 on waste and repealing certain Directives. Brussels: 695 European Parliament and the Council; 2008.

696 [23] EC. Review of Waste Policy and Legislation. ENV.C.2, 02/2013. European Commission, Brussels.

697 2013. Available at (2015-09-10): (http://ec.europa.eu/smart-

698 regulation/impact/planned ia/docs/2014 env 005 waste review en.pdf).

699 [24] EC. COM(2011) 571 final. Roadmap to a Resource Efficient Europe. European Commission, 700 Brussels. 2011.

701 [25] EC. $\operatorname{COM(2014)~} 398$ final/2. Towards a circular economy: A zero waste programme for Europe. 702 European Commission, Brussels. 2014.

703 [26] EC. COM(2015) 80 final. Energy Union Package: A Framework Strategy for a Resilient Energy

704 Union with a Forward-Looking Climate Change Policy. European Commission, Brussels. 2015.

705 [27] EC. COM(2014) 397 final. Proposal for a directive of the European Parliament and of the Council 706 amending Directives 2008/98/EC on waste, 94/62/EC on packaging and packaging waste, 1999/31/EC 707 on the landfill of waste, 2000/53/EC on end-of-life vehicles, 2006/66/EC on batteries and accumulators and waste batteries and accumulators, and 2012/19/EU on waste electrical and electronic equipment. Brussels: European Commission; 2014.

[28] Tobiasen L, Kamuk B. 8 - Waste to energy (WTE) systems for district heating. In: Klinghoffer NB, Castaldi MJ, editors. Waste to Energy Conversion Technology: Woodhead Publishing; 2013. p. 12045.

[29] CEWEP. Confederation of European Waste-to-Energy Plants. 2015. Web page available at (201509-10). (http://www.cewep.eu/).

715 [30] ESWET. Energise your waste! European Suppliers of Waste to Energy Technology. 2015. Web 716 page available at (2015-09-10): (http://www.eswet.eu/).

717 [31] Persson U, Werner S. Heat distribution and the future competitiveness of district heating. 718 Applied Energy. 2011;88(3):568-76.

719 [32] Persson U, Werner S. District heating in sequential energy supply. Applied Energy. 2012;95:12372031.

721 [33] Lund H, Möller B, Mathiesen BV, Dyrelund A. The role of district heating in future renewable 722 energy systems. Energy. 2010;35(3):1381-90.

723 [34] Gils HC. A GIS-based Assessment of the District Heating Potential in Europe. 12th Symposium 724 Energieinnovation, 15-17 Feb. Graz, Austria. 2012.

725 [35] Connolly D, Lund H, Mathiesen BV, Werner S, Möller B, Persson U, et al. Heat Roadmap Europe:

726 Combining district heating with heat savings to decarbonise the EU energy system. Energy Policy.

727 2014;65:475-89.

728 [36] Persson U, Möller B, Werner S. Heat Roadmap Europe: Identifying strategic heat synergy 729 regions. Energy Policy. 2014;74(0):663-81.

730 [37] Connolly D, Hansen K, Drysdale D, Lund H, Vad Mathiesen B, Werner S, et al. Enhanced Heating 731 and Cooling Plans to Quantify the Impact of Increased Energy Efficiency in EU Member States. 
733 Report: Executive Summary. Stratego: Enhanced Heating and Cooling Plans. Project No: IEE/13/650.

734 2014. Available at (2015-09-10):

735 (http://heatroadmap.eu/resources/STRATEGO/STRATEGO\%20WP2\%20-

736 \%20Executive\%20Summary\%20\%26\%20Main\%20Report.pdf).

737 [38] EU. Directive 2012/27/EU on energy efficiency, amending Directives 2009/125/EC and

738 2010/30/EU and repealing Directives 2004/8/EC and 2006/32/EC. Brussels: European Parliament and

739 the Council; 2012.

740 [39] EU. Council Directive 2013/12/EU, adapting Directive 2012/27/EU of the European Parliament

741 and of the Council on energy efficiency, by reason of the accession of the Republic of Croatia.

742 Brussels: European Parliament and the Council; 2013.

743 [40] ES. Municipal waste [env_wasmun]. Last update: 2014-12-09. Download date: 2015-01-30.

744 Eurostat. Luxembourg. 2015.

745 [41] ES. Generation of waste [env_wasgen]. Last update: 2015-07-23. Download date: 2015-08-08.

746 Eurostat. Luxembourg. 2015.

747 [42] Arena U. Process and technological aspects of municipal solid waste gasification. A review.

748 Waste Management. 2012;32(4):625-39.

749 [43] Tanigaki N, Manako K, Osada M. Co-gasification of municipal solid waste and material recovery

750 in a large-scale gasification and melting system. Waste Management. 2012;32(4):667-75.

751 [44] Arena U. Gasification: An alternative solution for waste treatment with energy recovery. Waste 752 Management. 2011;31(3):405-6.

753 [45] Münster M, Meibom P. Optimization of use of waste in the future energy system. Energy.

754 2011;36(3):1612-22.

755 [46] Connolly D, Vad Mathiesen B, Alberg Östergaard P, Möller B, Nielsen S, Lund H, et al. Heat

756 Roadmap Europe 2050 - Second pre-study for EU27. Euroheat \& Power, Brussels; 2013. Available at:

757 (http://www.euroheat.org/Heat-Roadmap-Europe-165.aspx).

758 [47] HRE. Heat Roadmap Europe - A low-carbon heating and cooling strategy for Europe. 2014. Web

759 page available at (2014-10-29): (http://www.heatroadmap.eu/).

760 [48] ISWA. Waste-to-Energy: State-of-the-Art-Report, Statistics, 6th Edition, August 2012.

761 International Solid Waste Association. 2012.

762 [49] EEA. The European Pollutant Release and Transfer Register (E-PRTR). Downloaded data category

763 (2013-07-08): eprtr_v4.2_mdb.zip. European Environment Agency, Copenhagen; 2013. Available at:

764 (http://www.eea.europa.eu/data-and-maps/data/member-states-reporting-art-7-under-the-

765 european-pollutant-release-and-transfer-register-e-prtr-regulation-5).

766 [50] CEWEP. Country Reports: 2010 Country Report on Waste Management. Confederation of

767 European Waste-to-Energy Plants. 2014. Available at:

768 (http://www.cewep.eu/information/data/subdir/442. Country Report on Waste Management.ht

769 ml).

770 [51] IndustryAbout. World industrial information. 2014. Available at: (http://industryabout.com/).

771 [52] CEWEP. Energy Report III (Status 2007-2010): Results of Specific Data for Energy, R1 Plant

772 Efficiency Factor and NCV of 314 European Waste-to-Energy (WtE) Plants. December 2012.

773 Confederation of European Waste-to-Energy Plants. Würzburg/Brussels. 2013.

774 [53] IEA. Energy Balances of OECD and Non-OECD Countries (2014 Edition). Extended Energy

775 Balances. Paris: International Energy Agency; 2014. 
[54] EC. Guidelines on the Interpretation of the R1 Energy Efficiency Formula for Incineration Facilities Dedicated to the Processing of Municipal Solid Waste According to Annex II of Directive 2008/98/EC on Waste. Directorate-General Environment. European Commission, Brussels. 2011. [55] Stengler E. On the Road to Recovery: Achieving R1 Status. Waste Management World. 2015. Web page available at (2015-09-15): (http://www.waste-managementworld.com/articles/2010/11/on-the-road-to-recovery-achieving-r1-status-.html).

782 [56] ES. Population on 1 January by broad age group, sex and NUTS 3 region [demo_r_pjanaggr3].

783 Last update: 2015-08-04. Download date: 2015-08-08. Eurostat. Luxembourg. 2015.

[57] ES. Municipal waste by NUTS 2 regions - pilot project [env_rwas_gen]. Last update: 2014-04-10. Download date: 2015-08-08. Eurostat. Luxembourg. 2015.

[58] ES. Number and capacity of recovery and disposal facilities by NUTS 2 regions [env_wasfac]. Last update: 2015-07-23. Download date: 2015-08-08. Eurostat. Luxembourg. 2015.

[59] Persson U, Werner S. District heating in sequential energy supply. Fig. 3.1. Applied Energy. 2012;95:123-31.

[60] Ayres RU. Use of material balances to estimate aggregate waste generation and waste reduction potential in the US: Fontainebleau, France, 1993.

792 [61] Ayres RU, Ayres LW. Use of materials balances to estimate aggregate waste generation in the

793 U.S. (excluding chemicals). Fontainebleau, France: INSEAD, 1993.

794 [62] Leontief W. Input-output economics. Oxford University Press, New York. 1966. Environmental Analyses. Statistisk sentralbyrå (Statistics Norway), Oslo-Kongsvinger. 1996.

[64] Alfsen KH. Use of macroeconomic models in analysis of environmental problems in Norway, and consequences for environmental statistics. Statistical Journal of the United Nations Economic Commission for Europe. 1992;9(1):51-72.

800 [65] Conrad K. Applied general equilibrium modeling for environmental policy analysis. Ann Oper Res. 801 1994;54(1):129-42.

802 [66] Johansen L. A Multi-Sector Study of Economic Growth. North-Holland Pub. Co, Amsterdam. 8031960.

804 [67] Johansen L. A Multi-Sector Study of Economic Growth. Second enlarged edition. North-Holland 805 Pub. Co, Amsterdam. 1974.

806 [68] Edmonds J, Reilly J. A long-term global energy- economic model of carbon dioxide release from 807 fossil fuel use. Energy Economics. 1983;5(2):74-88.

808 [69] Edmonds J, Reilly J. Global Energy and $\mathrm{CO}_{2}$ to the Year 2050. The Energy Journal. 1983;4(3):2180947.

810 [70] Bandara JS. Computable general equilibrium models for development policy analysis in LDCs. 811 Journal of Economic Surveys. 1991;5:3-67.

812 [71] Bergman L. Energy policy modeling: A survey of general equilibrium approaches. Journal of 813 Policy Modeling. 1988;10:377-400.

814 [72] de Melo J. Computable general equilibrium models for trade policy analysis in developing 815 countries. Journal of Policy Modeling. 1988;10:469-503.

816 [73] Shoven JB, Whalley J. Applied general equilibrium models of taxation and international trade: An 817 introduction and survey. Journal of Economic literature. 1984;22:1007-51.

818 [74] Bruvoll A, lbenholt K. Future waste generation forecasts on the basis of a macroeconomic model. 819 Resources, Conservation and Recycling. 1997;19(2):137-49. 

National Institute of Economic Research, Stockholm. 2006.

[76] Östblom G, Ljunggren Söderman M, Sjöström M. Analysing future solid waste generation - Soft linking a model of waste management with a CGE-model for Sweden. Working paper No. 118, May 2010. The National Institute of Economic Research (NIER), Stockholm. 2010.

[77] Sjöström M, Östblom G. Future Waste Scenarios for Sweden based on a CGE-model. Working paper No. 109, Feb. 2009. The National Institute of Economic Research (NIER), Stockholm. 2009.

[78] Sundqvist J-O, Stenmarck Å, Ekvall T. Model for future waste generation. IVL Report B1933.

Towards Sustainable Waste Management (ToSuWaMa). Swedish Environmental Research Institute Ltd. (IVL), Stockholm. 2010.

[79] Wooldridge JM. Introductory Econometrics: A Modern Approach. Fourth Edition. South-Western

831 Cengage Learning, Mason, Ohio. 2009.

832 [80] Skovgaard M, Moll S, Møller Andersen F, Larsen H. Outlook for waste and material flows: Baseline and alternative scenarios. ETC/RWM working paper 2005/1. European Topic Centre on Resource and Waste Management, Copenhagen. 2005.

[81] Skovgaard M, Villanueva A, Møller Andersen F, Larsen H. Environmental outlooks: Municipal waste. ETC/RWM working paper 2007/1. European Topic Centre on Resource and Waste Management, Copenhagen. 2007.

[82] Møller Andersen F, Skovgaard M, Larsen H. Municipal waste generation, management and greenhouse gas emission. Ch. 3 in "Waste and Environmental Policy", edited by Massimiliano Mazzanti \& Anna Montini: Routledge explorations in environmental economics. Routledge. Abingdon, Oxon, 2009.

[83] Møller Andersen F, Larsen H, Skovgaard M, Moll S, Isoard S. A European model for waste and material flows. Resources, Conservation and Recycling. 2007;49(4):421-35.

[84] Skovgaard M, Hedal N, Villanueva A, Møller Andersen F, Larsen H. Municipal waste management and greenhouse gases. ETC/RWM working paper 2008/1. European Topic Centre on Resource and Waste Management, Copenhagen. 2008.

847 [85] Bakas I, Sieck M, Hermann T, Møller Andersen F, Larsen H. Projections of Municipal Waste 848 Management and Greenhouse Gases. ETC/SCP working paper 4/2011. European Topic Centre on 849 Sustainable Consumption and Production, Copenhagen. 2011. on Waste Generation and Management. Headline Project Report. Final Report for the European Commission DG Environment under Framework Contract No ENV.C.2/FRA/2011/0200. 07/02/14. Eunomia Research \& Consulting (UK) and Copenhagen Research Institute (DK). Bristol and Copenhagen. 2014.

[87] EC. Waste management Model: EU Member State Municipal Waste Management Model. European Commission. 2015. Web page available at (2015-09-16): (http://www.wastemodel.eu/). European Union. Final Report. Study Contract Nr. 07.0307/2008/517621/ETU/G4. Arcadis, Deurne, Belgium. Eunomia Research Consulting, Bristol, United Kingdom. 2010. in Manufacturing Industries in Norway. Environmental and Resource Economics. 2003;26(2):227-48. [90] Gibbs A, Elliot T, Ballinger A, Hogg D, Gentil E, Fischer C, et al. Development of a Modelling Tool on Waste Generation and Management. Appendix 7: Distance to Target Modelling. Final Report for the European Commission DG Environment under Framework Contract No ENV.C.2/FRA/2011/0200. 07/02/14. Eunomia Research \& Consulting (UK) and Copenhagen Research Institute (DK). Bristol and Copenhagen. 2014. 
867 [91] Werner S. Possibilities with more district heating in Europe, Work Package 4 (WP4) of the 868 Ecoheatcool Project. Euroheat \& Power, Brussels; 2006.

869 [92] HUDHC. Halmstad University District Heating and Cooling Database. Halmstad University, 870 Sweden. 2014.

871 [93] Persson U. District heating in future Europe: Modelling expansion potentials and mapping heat 872 synergy regions. Dissertation Thesis. Series Nr: 3769. Göteborg: Energy and Environment, Chalmers 873 University of Technology, 2015.

874 [94] IEA. Energy Balances of OECD and Non-OECD Countries (2014 Edition). Summary Energy 875 Balances. Paris: International Energy Agency; 2014.

876 [95] ES. Heating degree-days by NUTS 2 regions - annual data [nrg_esdgr_a]. Last update: 2013-06877 26. Downnload date: 2015-09-17. Eurostat. Luxembourg. 2015.

878 [96] Füssel H-M. Heating degree days: Indicator assessment/Data and maps. European Environment 879 Agency, Copenhagen. 2012. Available at (2015-09-08): (http://www.eea.europa.eu/data-and-

$880 \mathrm{maps}$ /indicators/heating-degree-days-1/assessment).

881 [97] Füssel H-M. Trend in heating degree days in the EU-27:

882 Fig4.9_ENER01_Heating_degree_days.xIsm (Downloadable dataset). European Environment Agency, 883 Copenhagen. 2012. Avalable at (2015-09-08): (http://www.eea.europa.eu/data-and884 maps/figures/trend-in-heating-degree-days).

885 [98] Mazzanti M, Zoboli R. Waste generation, waste disposal and policy effectiveness: Evidence on 886 decoupling from the European Union. Resources, Conservation and Recycling. 2008;52(10):1221-34.

887 [99] Mazzanti M. Is waste generation de-linking from economic growth? Empirical evidence for 888 Europe. Applied Economics Letters. 2008;15(4):287-91.

889 [100] Sjöström M, Östblom G. Decoupling waste generation from economic growth - A CGE analysis 890 of the Swedish case. Ecological Economics. 2010;69(7):1545-52.

891 [101] WRAP. Decoupling of Waste and Economic Indicators. Final report. SAP142-002. Waste \& 892 Resource Action Programme, Banbury, Oxon. 2012.

893 [102] Mazzanti M, Zoboli R. Municipal Waste Kuznets Curves: Evidence on Socio-Economic Drivers 894 and Policy Effectiveness from the EU. Environmental and Resource Economics. 2009;44(2):203-30.

895 [103] EEA. The European environment - state and outlook 2010: synthesis. European Environment 896 Agency, Copenhagen. 2010.

897 [104] EEA. Diverting waste from Landfill: Effectiveness of waste-management policies in the 898 European Union. EEA Report No 7/2009. European Environment Agency, Copenhagen. 2009.

899 [105] EEA. The European environment - state and outlook 2015: synthesis report. Sections 4.1 to

900 4.4. European Environment Agency, Copenhagen. 2015.

901 [106] Bruvoll A. Taxing virgin materials: an approach to waste problems. Resources, Conservation and 902 Recycling. 1998;22(1-2):15-29.

903 [107] Sundberg J. Increased material recovery - What role will energy recovery play? Rapport

904 2015:11. Avfall Sverige AB, Malmö. 2015. Available at (2015-09-14):

905 (http://www.avfallsverige.se/fileadmin/uploads/Rapporter/2015-11.pdf).

906 [108] Persson U, Werner S. District heating in sequential energy supply. Fig. 3.3. Applied Energy. 907 2012;95:123-31.

908 [109] Rylander H, Wiqvist W. Assessment of Increased Trade of Combustible Waste in the European

909 Union. Rapport F2012:04. Avfall Sverige AB, Malmö. 2012. Available at (2015-09-14):

910 (http://www.avfallsverige.se/fileadmin/uploads/Rapporter/F\%C3\%B6rbr\%C3\%A4nning/F2012-

911 04.pdf).

912 